\title{
الجدران لها آذان : دراسة لغوية وتحليل الخطاب لفن الجداريات في جدة: المملكة العربية السعودية
}

\section{نهى الشرفا ، علاء الجوفي}

مستخلص. تهذف هذه المقالة اللغوية العلمية الى تقديم مفهوم جديد لفن الجداريات في مدينة جدة بالتركيز على الوظائف اللغوية كما تتقلها لغة هذه الجداريات حيث تعكس القيم الاجتماعية والثقافية الخاصة بمختلف نواحي

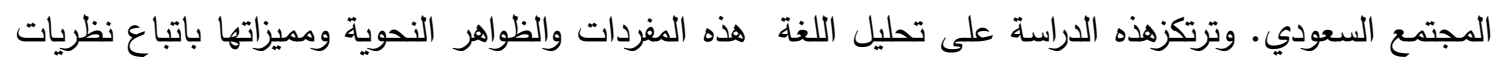
تحليل الخطاب النقدي (CDA) كما وضعها اللغوين فاندييك و فيركلوج (Van Dij and Fairclough) وطوراها لتشمل الثقافات اللغوية الاجتماعية . وتتكون بيانات الجداريات التي تخلو من التخريب أو من أعمال الشغب، والتي تم تجميعها لهذه الدراسة من وباتهات استخداما من مدينة جدة وجامعتي جدة وجامعة الملك عبد العزيز ، و أظهرت نتائج الدراسة أن هنالك أربعة أنواع


دينية والرابعة عبارات محظورة اجتماعيا لتعلقها بكلمات السب والألفاظ النابية ولكن تتحصر فيما يسمح بهاتهاتيه القانون. وتحظى الجداريات في جدة بميزات لغوية فريدة منها البساطة في التعبير والإبداع الخلاق والتتوع ويمكننا الاستتتاج أن الجداريات في جدة تحتوي على إبداعات متميزة يتفرد بها المجتمع السعودي، كما يرى كاتبي هذه المقالة أنها دراسة غير مسبوقة في علم اللغويات وتحليل الخطاب النقدي مما يجعلها تلاقي اهتمام علمي مميز لادى اللغويينالاجتماعين ومتخصصي علم النفسي والتعليم والإدارة بما في ذلك التربوين وإثراء لهذا التخصص من علم اللغويات. كلمات مفتاحية: تحليل الخطاب النقدي؛ فن الجداريات ؛ فن الشارع؛ القيم الغجتماعية-اللغوية؛ علم الغويات الإجتماعي 
53. Van Dijk, T. A. (1998). Ideology. A Multidisciplinary Study. London: Sage.

54. Wodak, R., \& Fairclough, N. (1997). Critical Discourse Analysis. In T. A. van Dijk (Ed.), Discourse as Social Interaction (pp. 258-284). London: Sage.

55. Wodak, R., \& Weiss, G. (2003). Critical Discourse Analysis. Theory and Interdisciplinary. Palgrave Macmillan.
56. Wronka, E. (2011). Attention modulates emotional expression processing. Psychophysiology, 48(8), 1047-1056.

57. Zuhairart. (2015, February 7) Late king Abdullah mural in Jeddah [Instagram post]. Retrieved from https://www.instagram.com 
confront the ideology behind the burqa". The Sydney Morning Herald. Archived from the original on 24 March 2018. Retrieved 29 April 2018.

35. Mangeya, H. (2014). Sociolinguistic analysis of graffiti written in Shona and English found in selected urban areas of Zimbabwe (Doctoral dissertation).

36. Matthews, N., Speers, L., \& Ball, J. (2012). Bathroom banter: Sex, love, and the bathroom wall. Electronic Journal of Human Sexuality, 15 (17), 1-11.

37. McCormick, J. (2003). "Drag me to the asylum": Disguising and asserting identities in an urban school. The Urban Review, 35, 111128.

38. Metz, H. (1992). (Ed.). Saudi Arabia: A Country Study. Washington: GPO for the Library of Congress.

39. Moukalled, D. (2013, November 12). Using graffiti to paint politics in the Arab world. Retrieved from http://english.alarabiya.net/en/views/news/mid dleeast/ 2013/11/12/Graffiti-as-a-means-ofpolitical-expression-in-the-Arab-world.html 40. Mwangi, F. G., Gathumbi, A. W., \& Bwire, A. M. (2012). Graffiti writing and its likely influence on English language learning in selected secondary schools in the larger

41. Naeem, H. (2013, March 6). Graffiti and the Arab uprisings - Culture \& Dialogue. Retrieved from https://lb.boell.org/en/2013/03/06/graffiti-andarab-uprisings-culture-dialogue

42. O'Doherty, D. (2012). 'Under siege? Exploring the hidden world of Irish Graffiti artists' Socheolas: Limerick student journal of sociology 42: 104-121.

43. Onyango, O. (2016). The talking walls of Rongo University College: A linguistic analysis of graffiti use at Rongo University College. International Journal of Academic Research in Progressive Education and Development, 5(1), 1-6.
44. Radwan, A. (2014). Urban street art as a sign of representing culture, economics \& politics of the cities. Journal of Fine Arts \& Architecture

45. Radwan, R. (2015, February 4). The mural that stole the nation's hearts. Retrieved from http://www.arabnews.com/art-

culture/news/699131

46. Raymonda (2008). The sociolinguistic study of graffiti arts used in Surakarta (Unpublished Master's thesis). Muhammadiyah University, Surakarta, Indonesia.

47. Rose, A., \& Christian S. (2005) Beautiful Losers. San Francisco: D.A.P./Iconoclast Ross, J. I (2016). Sorting it all out. In Ross, J. I. (Ed.), The Routledge Handbook of Graffiti and Street Art. (pp. 62-82). London: Routledge.

48. Saudi Arabia: State Schools to Allow Girls' Sports: Key Reforms to Male Guardianship System Still Needed. (2017). Human Rights watch. Retrieved fromhttps://www.hrw.org/news

49. Shaweesh \& Gharem (2013). A photo of Saudi track and field Olympian Sarah Attar [Pinterest post]. Retrieved from https://www.pinterest.com/pin/690176711618 $351202 / ? 1 \mathrm{p}=$ true

50. Smith-spark, L. (2018, June 22). The ban on Saudi women driving is ending: Here's what you need to know. Retrieved from https://edition.cnn.com/2018/06/22/middleeast /saudiwomen- driving-ban-end-intl/index.html 51. Before and after (n.d.) Women murals in Dammam [Snapchat post]. Retrieved from https://www.snapchat.com "The World of Banksy Art: A collection of news, knowledge, and miscellaneous Banksy art madness" (2012, October 11). Retrieved from http://banksyworld.blogspot.com

52. Van Dijk, T. A. (1993). Principles of critical discourse analysis. Discourse \& society, 4(2), 249-283. Retrieved from discourses.org/OldArticles/Principles.pdf 
12. Berg, B. L. 1., \& Lune, H. (2012). Qualitative research methods for the social sciences $\left(8^{\text {th }}\right.$ ed.). Boston: Pearson.

13. Blanchard, M. (2017). Saudi Arabia: Background and U.S. Relations. Washington D.C.

14. Bloch, S. (2012). The Illegal Face of Wall Space: Graffiti-Murals on the Sunset Boulevard Retaining Walls. Radical History Review, $2012 \quad$ (113): 111-126. https://doi.org/10.1215/01636545-1504930

15. Blommaert, J. (2005). Discourse: A critical introduction. Cambridge University Press. Retrieved from googlebook

16. Blume, R. (1985) Graffiti. In T. van Dijk (ed.), Discourse and literature. Amsterdam: John Benjamins, pp.137-148. doi: 10.1075/ct.3.09blu

17. Cole, C. M. (1991). Oh wise women of the stalls...'. Discourse \& Society, 2(4), 401411.

18. Claramonte, M. B., and Alonso J. I. G. (1993). 'Categories, morphological features and slang in the graffiti of a United States Western University' Revista Alicantina de Estudios Ingleses, (6), 19-31.

19. Crystal, D. (2001). Language and the Internet. Cambridge, Cambridge University Press. Retrieved from https://assets.cambridge.org/052180/2121/sam ple/0521802121ws.pdf

20. Davies, C., Maktabi, R., \& Abdelhaq, A. (2012, March 23). How to rebel, Saudi style. Retrieved from https://edition.cnn.com/2012/03/23/world/mea st/saudi-alternativeculture/ index.html

21. DeNotto, M. (2014). Street art and graffiti: Resources for online study. College \& Research Libraries News, 75(4), 208-211.

22. Fairclough, N. (1992). Discourse and social change. Cambridge: Polity.

23. Fairclough, N. (1995). Critical discourse analysis. The critical study of language. London: Longman
24. Fairclough, N. (2003). Analyzing discourse: Textual analysis for social research. Psychology Press.

25. Farnia, M. (2014). A thematic analysis of graffiti on the university classroom walls: A case of Iran. International Journal of Applied Linguistics and English Literature, 3(3), 4857. doi:10.7575/aiac.ijalel.v.3n.3p.48

26. Felemban, B. (2012, February 6). Let the walls speak visual Sunday. Retrieved from https://www.mashallahnews.com/let-the-wallsspeak/

27. Ferrell, J (2016). Graffiti, street art and the politics of complexity. In Ross, J. I. (Ed.), The Routledge Handbook of Graffiti and Street Art. (pp. 62-82). London: Routledge.

28. Ferrell, J. (1995). Urban graffiti: Crime, control, and resistance. Youth \& Society, 27(1), 73-

https://doi.org/10.1177/0044118X9502700100 $\underline{5}$

29. Gephart, R. P. (2004). Qualitative research and the academy of management journal. Academy of Management Journal, 47(4), 454-462.

30. Graffiti. (n.d.). In Oxford Dictionaries.com. Retrieved from https://en.oxforddictionaries.com

31. Gross, D. D., Walkosz, B., \& Gross, T. D. (1997). Language boundaries and discourse stability "Tagging" as a form of graffiti spanning international borders. Et Cetra, 54, 275-285.

32. Hanauer, D. I. (2004). Silence, voice and erasure: Psychological embodiment in graffiti at the site of Prime Minister Rabin's assassination. The Arts in Psychotherapy, 31(29), 35. doi.10.1016/j.aip.2004.01.001

33. Kariuki, G., Yieke, F, \& Ndoro, P. (2016). Graffiti on the walls: High school students in Kenya communicating their social issues. Journal of Applied Linguistics and Language Research, 3(6), 160-174.

34. Manea, Elham (27 August 2017). "Pauline Hanson's Senate stunt shows why we need to 
expressions; national expressions; social expressions; religious expressions; and finally, unacceptable expressions. Such discourse domains were sub-categorized in order to distinguish the way graffiti serve as vital means of social communication in Jeddah's society. The personal domain discourse was best treated under two headings: direct declaration of emotions, and indirect declaration of emotions as graffitists reflect directly or indirectly their life's challenges and happiness inscribed on walls. The national theme display ideals of three subclasses: Praising kings, affirming identities, and supporting national teams. Social change depicted social changes on Jeddah's wall which deal with the Saudi culture through the voice of art.

Ideology expressions are illustrated in different forms such as preaching, prayers, and supplications. This discourse genre reflects socio-cultural relations in the Saudi society. The dysphemism expressions, on the other hand, include three different subclasses: personal, ideological, and sexual taboo. These expressions have been found the least to occur and restricted to bathrooms' doors and hidden places.

Linguistic features of graffiti are found in versatile forms of one word sentences, simple, complex nominal sentences, monologues, dialogues, or a combination of drawings, symbols, and logos that play a big role in discourse. Graffiti of the university students promote students' educational, personal, cultural, and social background. All these notions set graffiti in an important place as a subject matter and recommend further analysis.

\section{LIST OF REFERENCES:}

1. Abu Shaal, M. (2014, June 16). Graffiti began to impose its presence in the Kingdom. Retrieved from http://www.al$\underline{\text { madina.com/article/312632/ }}$
2. Akmajian, D., Demers, R., Farmer A., \& Harnish, R. (2001) Linguistics: An Introduction to Language and Communication. MIT Press

3. Al Abdali, S. (n.d.). Bibliography. Retrieved from http://edgeofarabia.com/artists/ 4. Al-Khawaldeh, N. N., Khawaldeh, I., Bani-Khair, B., \& Al-Khawaldeh, A. (2017). An exploration of graffiti on university's walls: A Corpus-Based Discourse Analysis Study. Indonesian Journal Of Applied Linguistics, 7(1), 29-42.

5. Al-Mansouri, A. (2014, March 29). The power of single letter graffiti in Saudi Arabia. Retrieved from http://english.alarabiya.net/en/life-style/artandculture/ 2014/03/29/The-power-of-singleletter-graffiti-in-Saudi-Arabia.html

6. Al-Sharif, F. (2018, March 1). Streets come to life in Saudi Arabia's first: Graffiti project. Retrieved from http://www.arabnews.com/node/1256736/saud i-arabia

7. Baird, J., \& Taylor, C. (2016). Ancient graffiti. In Ross, J. I. (Ed.), The Routledge Handbook of Graffiti and Street Art. (pp. 92111). London: Routledge.

8. Banksy. (2005). Wall and piece. Random House.

9. Banksy. (2012). Banksy: you are an acceptable level of threat and if you were not you would know about it. Darlington: Carpet Bombing Culture.

10. Bar'el, Z. (2017, August 30). Beyond Protest Art: A New Wave of Graffiti is Coloring the Arab World. Retrieved from https://www.haaretz.com/middle-eastnews/

MAGAZINE-beyond-protest-art-a-new-waveof-graffiti-is-coloring-the-arabworld1.5446491

11. Bates, L. (2014). Bombing, Tagging, Writing: An Analysis of the Significance of Graffiti and Street Art. Tese de Mestrado. Pensilvânia: University of Pennsylvania 
to uncover students' psychological status as well as strengthen students' bond.

Blume (1985) summarized the linguistic functions of graffiti: the "cognitive function of language" (von Polanz) and the "poetic function of language" (Jakobson). She stated that "the cognitive function of language" in Von Polanz's sense is when "speakers use language as a means of intentionally expressing perceptions, sensation, memories, plans, opinions ...etc., but without a partner relation or even a relation to particular personal action" (p. 145). She also explains that "the poetic function of language" as Jakobson interpreted can possibly be compared to all four addressee types. With reference to the creative and aesthetic motivation of graffiti construction, she pointed out that poetic language is found to be of a more than average frequency in graffiti, because it has a tendency to use specific language devices and discourse in advertising slogans and newspaper headlines, children rhyme ...etc. She concluded that the poetic devices of parody and contra fact of given formulas are features of graffiti.

Overall, the beliefs presented in the previous sections support Van Dijk's notion of power as control. He states that discourse power involves different access to social power. He sees social power as a kind of control. Therefore, the groups who has social power, they can control other groups' minds and actions. Since language can be associated with ideological means (Wodak \& Weiss, 2003) power is expressed through ideology as well as language (Fairclough, 1995). In this study, graffiti and street art have been used in Jeddah as a means of empowering the people of the society. It communicates messages in public places that are accessible to all, and acts as a tool for activism and a crucial reflection element of the society. It turns out to be a dynamic means of protest to bring about social change for communities of people who have no voice.

In short, the results of this study hold the potential to contribute significantly to the body of research of both fields: Discourse studies and sociolinguistics as they gave a thoroughly analysis of language use in society. The results showed that graffiti can be seen as a marked reflection of the Saudi society and presented a new generation interpretations of events and thoughts. This project can open public minds to the notion that graffiti is a legitimate art form when presented in a legal setting. The present study is also expected to be very valuable to the civil society and its members through addressing and highlighting social issues. Official institutions (i.e. identified with a social purpose), and the educational settings may find their interest in this project as the results may be useful not only for Saudi society as a whole but also to the university students, educators, administrators, and parents in specific. People in charge can consider the results and create a conducive learning environment, which allows for a free exchange of feelings. They can also construct a graffiti stand in each college, a place in an institute, or even in the street to make people (e.g. students) legally write their concerns regarding daily life and hire a professional social worker to reply back to their issues with solutions.

\section{Conclusion}

The paper has investigated the communicative functions and linguistic features of graffiti in Jeddah, Saudi Arabia within the framework of Critical Discourse theory (CDA) as outlined by Van Dijk and Fairclough. Saudi graffiti show Saudis' thoughts and emotions and are found as a form of social practice, a product of the practices of various institutions. Qualitative modes of enquiry for (229) graffiti, with regard to thematic classification yielded five categories that underline graffiti types in Jeddah. These categories are personal 
bathroom's doors) or a combination of drawings, symbols, and logos that play a big role in discourse. It was also interesting to find that every graffiti writer has a different visual and linguistic casual daily life style. Each tag or portrait displays an aesthetic sense of its owner and correlates with calligraphy as much as language.

Furthermore, one of the most noticeable features of graffiti discursive practices was language variation. Graffiti used both standard Arabic and the casual and the vernacular Arabic (i.e. Hijazi), and occasionally standard English. They also used a combination of alphabet letters, numerals, and emoticons, which are employed to convey effective messages. It is worth mentioning that Arabic has been preferential language found in graffiti samples. Most of the written graffiti were presented in vernacular Arabic, while standard Arabic was only used in citing verses from Qur'an and picking certain lines from poetry, and quoting common proverbs. This can be ascribed to the fact that the standard Arabic is considered a prestigious language.

Graffiti language includes the following types: sub-sentential phrase (i.e. phrases with no finite verb), sentential (i.e. of or relating to a sentence), supra-sentential (i.e. a sequence of sentences-paragraph). These sentences were written in different forms: statements, dialogues, commands, exclamations, conditionals, and questions. With regard to the sentence construction, graffitist tended to employ simplicity and shortness to be easily remembered. Some of the statements are fragments (i.e. simple or syntactically less complex and void of punctuation marks).

Vocabulary choice by graffitists tends to use short content words rather than functional words to directly communicate thoughts making the messages notable and deeper; such as,"سلمان"(Salman), ، الاتحاد") (unity), "(الحب"(love). The frequency of short words seem to indicate that the viewer will lexically extend them to properly understand their intended meaning.

Comparing to other communication channels, graffiti were found to be of relatively more taboo language due to the anonymity of the graffiti writers and abbreviation caused by lack of time and space (e.g. I $\bullet$ U, WTF). On the other hand, the spelling system is similar to everyday language except some intentional typo which can also be attributed to lack of time and space. It was noticed that certain words were spelled differently as "you", "u", " $y$ " as a casual language. Concerning English expressions, it is worth noting that graffitists sometimes use loanwords as an impact of the social media among the youths' preference of technical language over the standard ones (e.g. LOL-laughing out loud), Crystal (2001), where there is great influence on the variety and creativity of language. He argues that the phenomenon of "Netspeak" is going to "change the way we think" about language in a fundamental way, because it is a linguistic singularity - a genuine new medium.

With regard to the discourse structure, it was found that graffiti collected from restrooms written by females appeared to be in dialogue form. One woman started the dialogue by asking a question or stating an issue and others provided a series of replies and serious responses. Mc Cormick (2003) claims that graffiti provides people with a great opportunity to escape from the strictness to construct a space framework for a more spontaneous discourse by attracting uninhibited and uncensored discussions that are often rare in academic writing. Studying graffiti produced by American female university students, Cole (1991) found that the writing was mainly interpersonal, interactive, advisory, and relationship-oriented. In other words, graffiti dialogues found in campus restrooms doors and walls indicated that graffiti is not only serves its purpose as a mode of communication but also serves as a means 


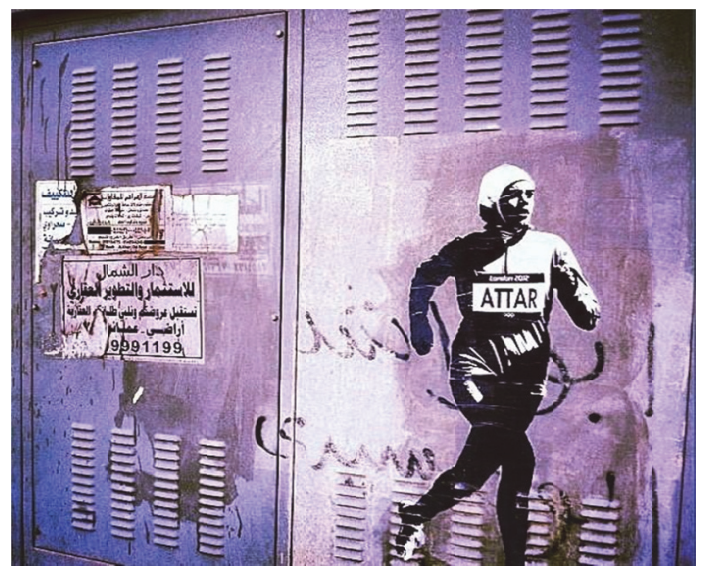

\section{Figure 8. Sara Attar mural in Jeddah (Shaweesh \& Gharem, 2013)}

As the above graffiti of figure 8 above shows, in 2013, the Saudi Artist Shaweesh and the artist collective Gharem Studio created lifesize graffiti art honoring Saudi track and field Olympian Sarah Attar's run into the history books as one of the first two Saudi women to participate at the Olympics. (Shaweesh \& Gharem, 2013).

\subsubsection{Expressions of Dysphemism (i.e.} taboos)

Taboo words are those that are to be avoided entirely, or at least avoided in 'mixed company' or 'polite company.' (Akmajian \& Demers, 2001). In other words, "a taboo is a social or religious custom prohibiting or forbidding discussion of a particular practice or forbidding association with a particular person, place, or thing," (Oxford dictionary.com). "What counts as taboo language is something defined by culture, and not by anything inherent in the language," (Akmajian \& Demers, 2001). Current studies reveal that graffiti conveying taboo words and expressions have been found to be the least frequent occurrence and restricted to bathrooms' doors and hidden places. They are found under the subcategories of personal, ideological and sexual taboos, as in table 12 below:

Table 12. Expressions for personal, ideological and sexual taboos

\begin{tabular}{|c|c|}
\hline taboo expressions & Translation \\
\hline يا حيو انه & You are an animal \\
\hline أتنمنى اتعرف عليكم عشان اشبشبكم & I want to beat you with my sneakers \\
\hline الله يلعنكم & God damn you \\
\hline 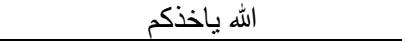 & May God take your soul \\
\hline WTF & WTF \\
\hline
\end{tabular}

\subsection{Distinctive morpho-syntactic features of graffiti}

The data yielded a total of 229 written and pictorial graffiti. Interestingly, graffiti was observed to present a unique style of writing.
Syntactically, forms are presented in one word sentences, simple, complex nominal sentences, monologues (consisting of a number of sentences), dialogues, where each turn is made a short time after the last (e.g. on university 
Table 4 above involve expressions which express natives' devotion to their tribes (such as Ghamed) which reflect their feeling of belonging and affiliation in public. Social identity isn't hidden as the main self-identity expression focused on their surnames as well.

\subsubsection{Supporting National Teams}

Saudis express their love and devotion to their football teams and players such as football national team (i.e. Al-Itihad and Al-Ahli), as in table 6 below:

Table 6. Expressions for Supporting National Teams

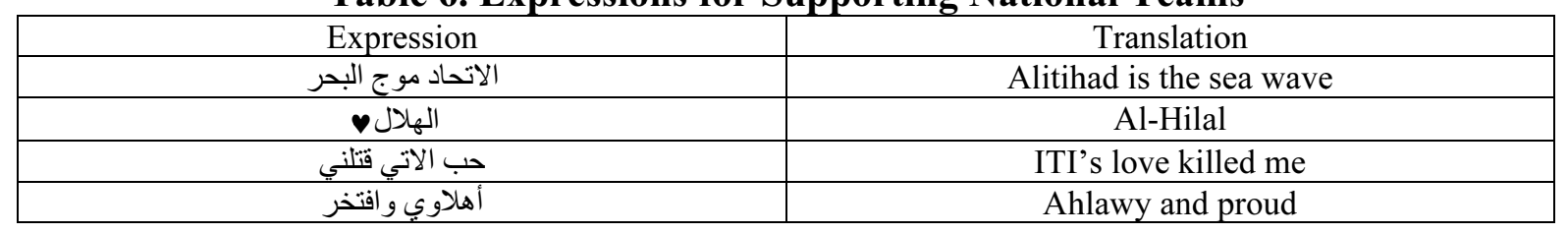

Table 6 above reaffirms the major social values through some expressions are used by Saudis to support their national teams.

\subsubsection{Ideology themes}

It is worth mentioning that Saudi Arabia's socio-cultural practices are based on tradition and religious ideology, (Metz, 1992). In
2018, King Salman issued the decree concerning women right to drive and ended ban on women drivers (Smith-spark, 2018). Graffiti as a direct reflection of the environment, figure 6, a Saudi graffitist draws a portrait in Jeddah streets on the walls that is worth a thousand words:

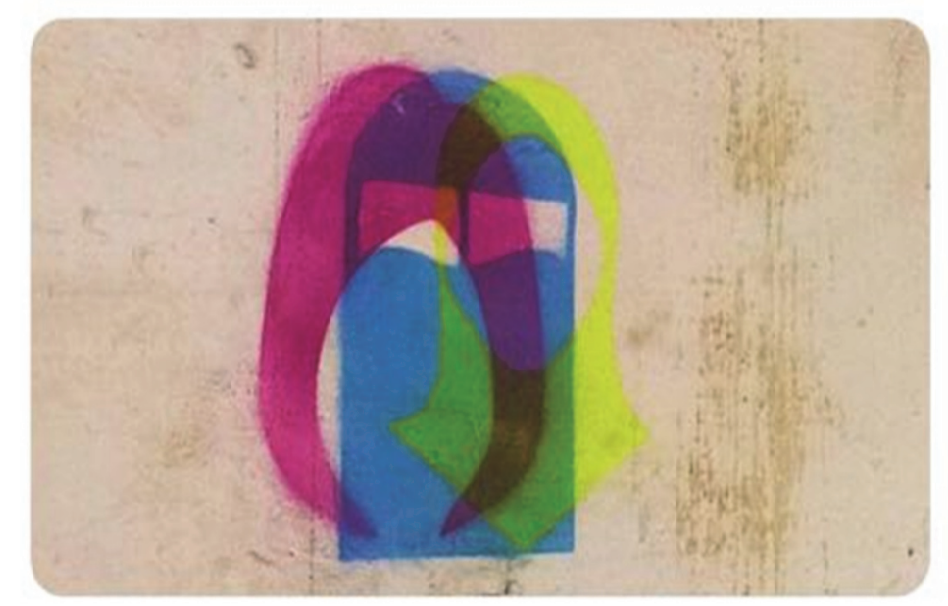

Figure 7. Women dress code mural in Jeddah (Saudi Art Guide)

The portrait in figure 7 above, shows three different images of women in Jeddah. Three different forms of women's appearance are contrasted with each other in Saudi society. Niqab covers the whole face, showing only eyes, while Khimar covers the hair, neck and shoulders. On the other hand, the third form is a Muslim woman not wearing Hijab.

Moreover, figure 8 below is a graffiti for a young athlete woman, named Sara Alattar, who participated for the first time on Saudi women's history at the Olympics: 


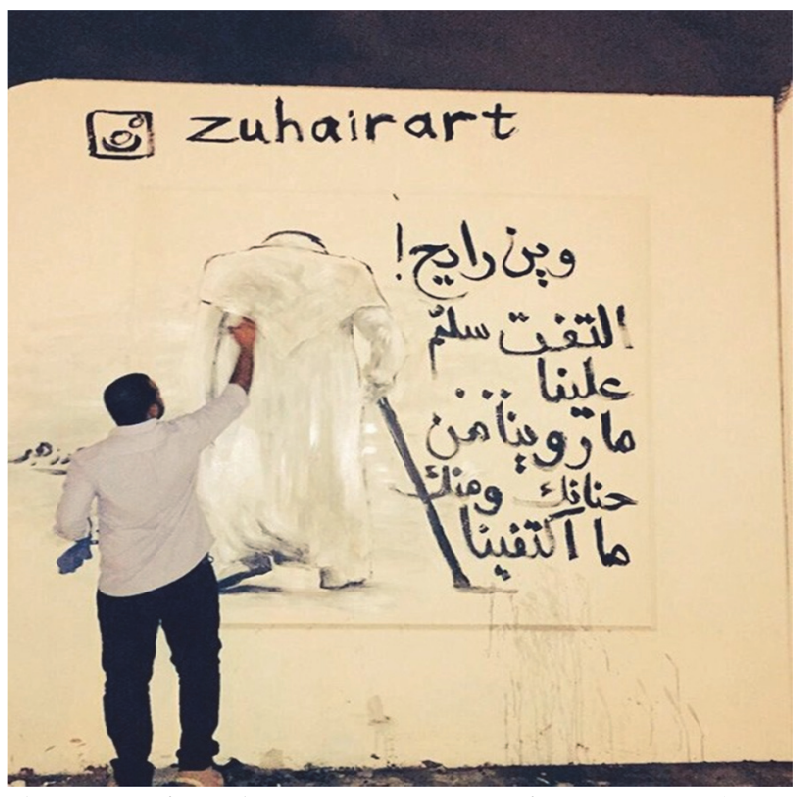

Figure 6. Late king Abdullah mural in Jeddah (Zuhairart)

The mural, which decorates the wall on the sea front of Jeddah Corniche, has become a landmark and many visitors have been to the area to see it and take selfies.
National graffiti also set out in the University of Jeddah where students to write to express their feel towards the country as Table 4 below reveals:

Table 4. Examples of the national themes expressed in graffiti

\begin{tabular}{|c|c|}
\hline National expressions & Translation \\
\hline اللهم احفظ ملكنا وبلادنا واحفظ امننا واستقر ارنا & $\begin{array}{l}\text { Oh God save our King and our country and preserve } \\
\text { our security and stability }\end{array}$ \\
\hline احبك يا سلمان & I love you, Salman \\
\hline جميل أن يموت الإنسان من أجل الوطن & It is beautiful to die for the homeland \\
\hline الوطن هو قلب وروح الانسان & Homeland is the heart and soul of man \\
\hline الوطن هو حياتنا & Home is our life \\
\hline وطني دمت فخر المسلمين & My home, stay the national pride of Muslims \\
\hline
\end{tabular}

Table 4 above demonstrates some examples of these national expressions with their translation. Examples mirror students' dedication to the kingdom.

\subsubsection{Social identity}

Saudi tended to express their social identity through different discursive means such as nicknames and other related self-identity that imply belonging and societal family ties. Table 5 below, social identity expressions are illustrated with their subcategories.

Table 5. Social identity expressions illustrated in graffiti

\begin{tabular}{|c|c|c|}
\hline Subcategory & Examples & Translation \\
\hline \multirow[t]{3}{*}{ Family name } & عزوتي غامد & Ghamed is my pride \\
\hline & تربة + الديرة & Taraba is a homeland \\
\hline & الهيلا و لا غيرنا هيلا & None is Hila but us \\
\hline \multirow[t]{2}{*}{ Nicknames } & عروج + أبو فرج & Arooj+ Abu faraj \\
\hline & المعلم - ل المع & The teacher \\
\hline Names & هشام - نوره ـاحمد & Hisham-Noura- Ahmed \\
\hline
\end{tabular}


been painted in less crowded areas and toilets' walls.

\subsection{Communicative functions}

Qualitative thematic analysis of the graffiti samples reveals that they serve various communicative functions within distinctive themes. Results obtained with respect to each theme are presented in the sections below.

\subsubsection{Personal themes}

Personal expressions are inner feelings towards family, friends, professors, or even strangers. They simply reflect mental, and emotional state to joy, love, and hate experienced by people throughout their life. Moreover, graffitists inscribe on walls and also draw pictures besides attractive statements regardless of visual techniques. The different styles however help express the individuals' feelings.

\subsubsection{Direct and indirect Declaration of Emotions}

As direct expressions are the best direct indicators of affective attitudes and dispositions (Wronka, 2011), graffiti writers tended to employ explicit words in either Arabic or English or sketches of a heart with names on it to symbolize their love. The most common expressions found on Jeddah's walls were the English words "I love X" or the Arabic words "X أحبك " where X is first name of a male or a female.

Table 2. Examples of direct declaration of emotions

\begin{tabular}{|c|c|}
\hline Direct Personal Expressions & Translation \\
\hline حبك عذاب & Your love is torturing \\
\hline No love & No love \\
\hline الامور طيبة & Everything is fine \\
\hline ارحموني & Have mercy on me \\
\hline حتى ناس زي الناس ما فيه & People are being different than expected \\
\hline هذي نتيجة قبول النسب الضعيفة في الجامعة & $\begin{array}{c}\text { This is the result of accepting low achievers at the } \\
\text { university }\end{array}$ \\
\hline
\end{tabular}

Graffiti on table (2) above involve personal themes of direct and indirect declaration of emotions that are inscribed on street walls or inside the universities.

\subsubsection{National theme}

Not only are the vast majority of wall graffiti works written in simple Arabic, but the use of creative language along with impressive paintings turn inscriptions into street art, demonstrating a great level of allocation and allowing the whole transaction to be perceived as society's communication to society.

\subsubsection{Praising kings}

Saudis show their strong love, attachment, and support to their country and their leadership. As the whole nation was mourning over late King Abdullah's death, Saudi graffitist, Ahmed Zuhair, has made his own personal painting to express his grief for the loss of the beloved monarch. It illustrates the late King walking away on his stick with a caption that says: "Where are you going? Please look back and say hello to us. We are still in need of your tenderness and we have not had enough of you." 
The choice of graffiti written in Arabic and English is mainly informed by the fact that the researcher is a fluent bilingual speaker of the two languages involved. Graffiti inscriptions involve code-switching between Arabic and English. For the purpose of this study, both written and pictorial graffiti, as a picture is worth a thousand words, are considered. The Arabic graffiti, however, were translated except for the Quranic citations, which are taken from Alquranenglish.com.

\subsection{Data Analysis}

Data are qualitatively analyzed. Percentages and frequencies of the graffiti-writings were ignored as the idea of applying statistical tests to a qualitative study is fundamentally invaluable because the purpose of employing a qualitative analysis is to search for "the meanings, concepts, definitions, characteristics, metaphors, symbols, and description of things" and not to their "counts or measures" (Berg \& Lune, 2012, p.3). So, the aim of qualitative study springs up from the fact that we seek to look beyond numbers and investigate further the phenomena that were not understood by using numbers. It looks to answer questions like "what", "where", and "how", (e.g., Gephart, 2004). Graffiti-writings for the present study were recorded and then transcribed for further analysis. All the examples provided in the next section were presented in their original form in order to help get the message intended by the graffitists. The data samples are analyzed at the functional, lexical, and syntactic levels. They were categorized into 5 discourse domains to classify graffiti in Jeddah. These are personal expressions, national expressions, social expressions, ideological expressions, and finally dysphemism expressions. These discourse domains were sub-categorized to distinguish the way graffiti serve as a vital means of social communication in Jeddah's society. Table 1 below provides an explanation of the proposed categories and subcategories at the functional level of analysis.

Table 1: Proposed categories/subcategories at the functional level of analysis in Jeddah

\begin{tabular}{|c|c|}
\hline \multicolumn{1}{|c|}{ Category } & Subcategory \\
\hline Personal themes/ communicative functions & Direct and indirect declaration of emotions \\
\hline National themes & Praising kings \\
\cline { 2 - 2 } & Confirming identity \\
\cline { 2 - 2 } & Supporting national teams \\
\hline ideological themes & Reaffirmation of faith \\
\hline Dysphemism themes & Personal, ideology and Sexual taboos \\
\hline
\end{tabular}

To eliminate possible categories overlapping, some characteristics are given for each category to differentiate one sub-category from the other. In "personal themes", for example, while "direct declaration of emotion" refers to messages in which the graffitists directly stated their feelings on their own words, "indirect declaration of emotion" involves indirect messages using three main tools: poetic citations, prosodic (i.e. proverbs), and songs (lyrics).

\section{Results and discussion}

Below is the analysis and discussion of the 229 graffiti of which the majority have been apparently written on the public walls in Jeddah streets. Very few, mainly taboos, have 
the emergence of an array of personal, social, and environmental needs.

Banksy's political content is generally accepted by many people around the world. In figure 4 below, Banksy's Armored Dove is one of the nine images painted on the West Bank
Wall as a means to criticize the PalestineIsraeli conflict (Banksy, 2012). The mural shows a white dove with its wings out wide in an open arm stance with an olive branch in its beak (i.e. reference to the biblical story of Noah and the Ark) (Banksy, 2012).

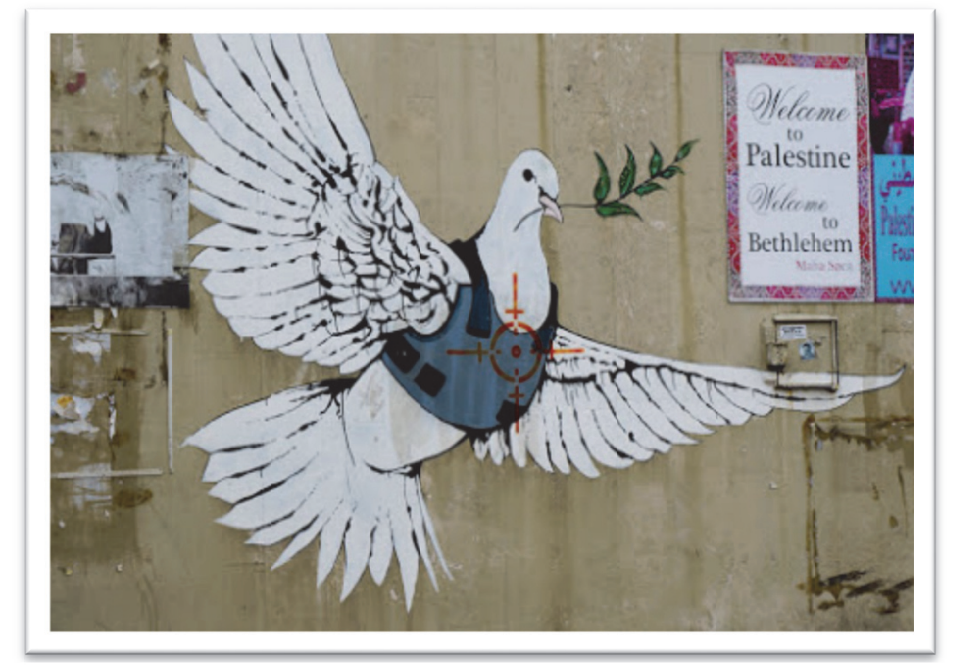

Figure 4. Banksy's white dove in Bethlehem (The World of Banksy Art)

Banksy's dove wears an armored vest with a target pointed at its chest, demonstrating that conflict on the West Bank is inevitable (Banksy, 2012). Graffiti are almost found everywhere on the walls of public buildings, on the seats of public transportations, on the doors of washrooms at colleges, schools, institutes as well as roads and highways. They also can be placed on semi-permanent and/or moveable items, like park benches, trash/garbage cans/bins, street signs, mail and newspaper boxes, and means of transportation, such as freight trains, metro/subway cars, buses, trucks, vans, and cars (Ross, 2016).

\section{Methodology}

\section{1 objectives and questions}

The study attempts to investigate the functions that graffiti serve (i.e. the thematic analysis of the written and pictorial data), and the distinctive lexical and syntactic features that characterize the language of graffiti in Jeddah's walls, Saudi Arabia. On account of these objectives, we aim to find an answer to the following questions: (1) What communicative functions do graffiti serve? And (2) What are the distinctive lexical and syntactic features that characterize the language of graffiti?

\subsection{Data Collection}

This corpus-based discourse analysis study is a total of 229 Discourses were drawn from messages written and illustrated on Jeddah's walls. The randomly selected sample consists of graffiti found in representative places in the city including two universities: University of Jeddah, King Abdul-Aziz University and popular areas in the north and the south of the city for the intention that results generalize the entire province. Graffiti samples have been collected for the study analysis during the years 2017-2018 and 2018-2019. Graffitiwritings were written in two major languages: Arabic (first language) and English (second language). 
provides an opportunity to understand graffiti as a product of human linguistic expression as well as the nature and impact of the message being conveyed (Onyango, 2016).

\subsection{Critical Discourse Analysis frame for Graffiti}

Critical Discourse analysis (CDA) is an interdisciplinary approach to the study of discourse that views language as a social practice in which language users operate in a set of cultural, social and psychological frameworks (Van Dijk, 1993). It investigates the way social power, cruelty, dominance and discrimination are represented by text and talk in the social and political context (Van Dijk, 1998). This view is also supported by Wodak \& Fairclough (1997) who assert that power relations, culture, history, and society are depicted in discourse. It can therefore be assumed that CDA can offer interpretation and description for graffiti as a form of social action.

As stated by Fairclough (1995\& 2003), discourses do not only represent the world, but also signify, constitute, and construct the world in meaning. There seems to be some evidence (e.g. Van Dijk, 1985; Claramonte \&Alonso, 1993; Whiting \& Koller, 2007; Mangeya, 2014) to indicate that graffiti can rightfully be named "discourse" as they follow discursive norms and conventions.

Fairclough (1992) also describes three levels of analytical approach of Critical Discourse Analysis. Figure 4 below illustrates Fairclough's three-dimensional conception of discourse and its three levels of analysis.

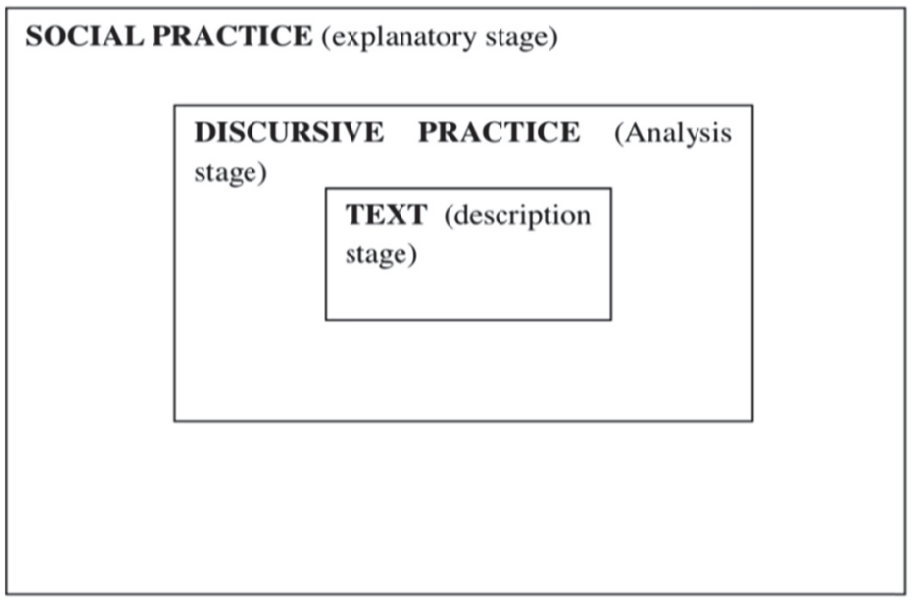

Figure 4: Fairclough's three-tier analysis model (adapted from Fairclough, 1992, p.73)

It can clarify, explain, and reflect the principles of the socio-cultural issues. Thus, it is significant to shed light on the importance of studying graffiti as a product of human interaction and the reflection of society as conveyed on graffiti messages.

\section{Literature review}

Researchers tended to classify graffiti based primarily on its content, composition, and/or overall aesthetic rather than the illegal/legal or sanctioned versus unsanctioned criteria (Ross,
2016). Bloch (2012) depicted the walls, which are covered with graffiti-murals, as "those produced by self-described, acknowledged, and active members of the graffiti community in public view with, primarily, the use of aerosol spray paint." (p. 124).

Graffiti-murals are a visually thematic technique whereby a painting or an photographic image, letters or characters are transferred to a wall surface not only to enhance a buildings plain wall, but also made 


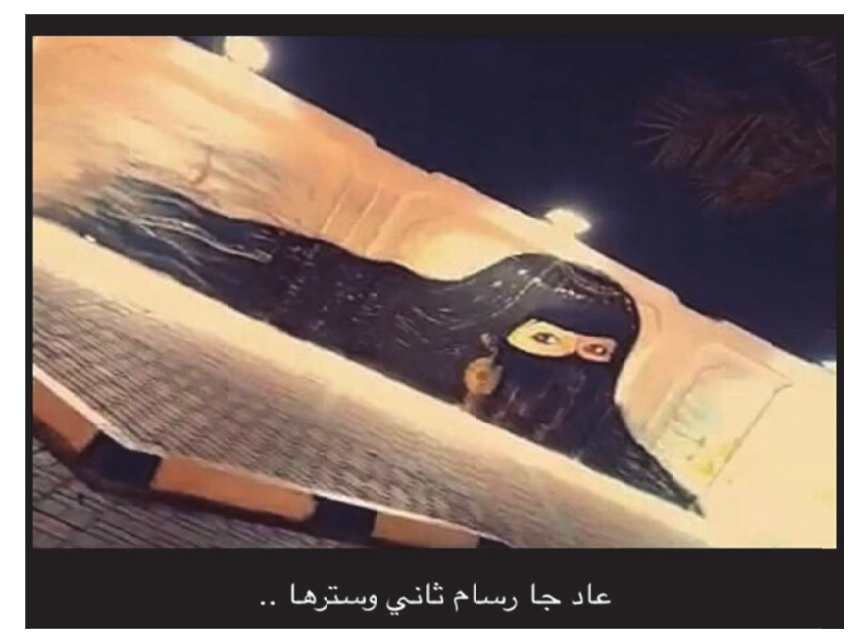

Figure 3. Woman mural in Dammam (Before and after account on snapchat)

Graffiti in Saudi Arabia is gaining an increasing reputation and many artists, whether famous or anonymous, are taking advantage of the streets' walls to post their views and emotions to the public. Graffiti in Saudi can be seen as an unconventional medium or as an alternative form of personal communication that is free of ordinary social limitations to stress out significant social issues and problems. In fact, we can't deny that graffiti is human products and forms of communication which can be inferred, examined, and understood (Gross et al.,1997).

\subsection{Statement of the problem}

By examining the types of graffiti practice illustrated in the society, the current study reveals vital information about the discourse of the graffitists, (DeNotto, 2014).

Since graffiti in Jeddah are generally associated with anti-social behavior, no previous studies on Saudi graffiti in general and Jeddah graffiti in particular have been documented. The paper argues that although graffiti are neglected art, they can provide people with an informal space to create alternative discourses. This, therefore, tends to offer the motivation to understand how graffiti are influenced by the sociolinguistic factors by which various social groups produce social relationships of power. Graffiti can also be considered a vital source of data for inspiring linguistic studies to concentrate on analyzing discourse patterns, examining various cultural production, and investigating gender-based language differences (Farnia, 2014). They are not only viewed as a source of present vital information, but also as an indicator to the future actions or intensions (DeNotto, 2014).

\section{Theoretical framework}

The examination of graffiti is based on the Critical Discourse theory (CDA) as outlined by Van Dijk and Fairclough. It is important to keep in mind that some of the previous studies (e.g. Kariuki et al, 2016; Al-Khawaldeh et al. 2017) exploring graffiti applied the CDA as the analysis of framework to the graffiti text, discursive practices, to the social context. Since graffiti is a form of discourse, it is essential to analyze it in the context of power relations in the society. Graffiti is taken as a social practice. It is considered as a social phenomenon that exists as a direct result of human interactions. It is not only a mixture of colorful drawings, words, and symbols, but also a vital tool to better understand the cultural attitudes deeply embedded within a particular community. Accordingly, this article 
Ahmad Zuhair Al Garni uses his paint brush and tool of choice to express his feelings (Radwan, 2014). The passing of the late King Abdullah bin Abdul Aziz had artists express their sorrow for the loss in many ways. It is not only a mural that express this sorrow, but it also speaks of the feelings of a whole nation (Radwan, 2014\& 2015).

Later on, streets were turned into inferential paintings in Saudi Arabia's first graffiti project in a historic neighborhood. About 20 Saudi graffiti artists coordinated for 10 days to complete a project, painting for six houses, transforming an entire neighborhood on Alkhobar's southern side which is believed to be the first street graffiti project in the Kingdom, (Al-Sharif, 2018).

Figure (2), below, is an anonymous artist mural in Dammam (a city in the Eastern Region of Saudi Arabia) for a woman showing her entire face with full makeup. Her long hair is reveled without the traditional veil. At first glance, people outside the Saudi society would think that this picture may represent a typical Saudi woman. However, the interpretation is attributed to the fact covered in public by the majority of Saudi women. The anonymous artist tended to depict the beauty of women face regardless of the society's criticism. It represents the society's attitude to unveil face in public.

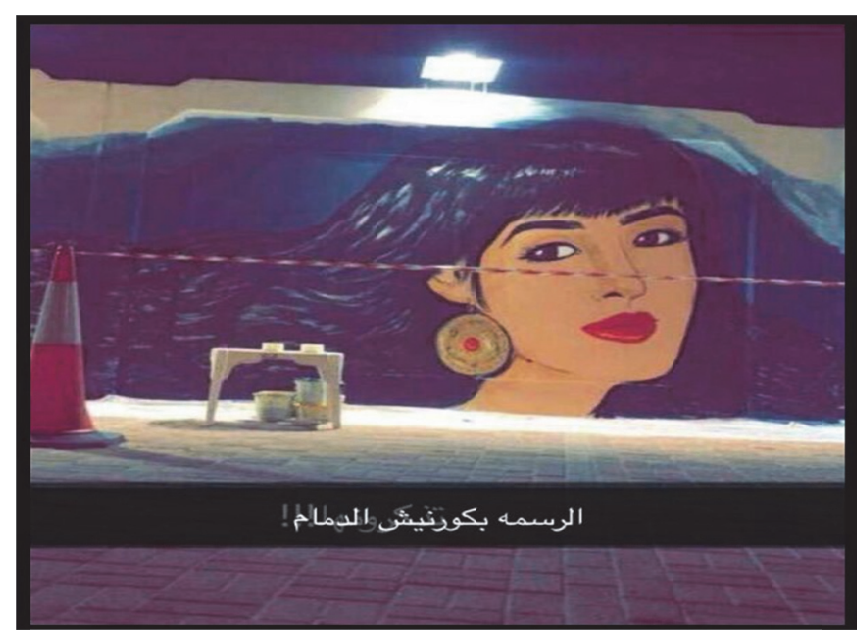

Figure 2. Woman mural in Dammam (Before and after account on snapchat)

Figure 3 below, is the same mural as that in figure 2 above, but was redrawn by another artist who added a veil to cover the woman's face and removed her makeup and her jewelry as a symbol of modesty. By doing this, the artist conveys the traditional message of wearing the veil and covering the entire face in public except for the eyes. The blue background changes to a light colour, the hair overlaps with the background to imply that the woman is putting on "niqab" and "tarhah" or "shilah", which are Arabic terms to relate to a face-cover and a head scarf.

These two contrasting versions of the same portrait represent the society's opposing sides: the supportive of the "نقاب", "niqab" (face cover), and the liberal side which calls for freeing females of it, (Manea, 2017). 
WAX or T7 (Felemban, 2012). Graffiti began to impose its presence in the Kingdom in recent years as a form of street art and becomes more popular and more appreciative by Saudis, especially in Jeddah which is considered the center of graffiti in the country (Abu Shaal, 2014) and (Blanchard, 2017).

Graffiti and street art represent cultural importance through its distinctive nature, its capability to decorate and enrich public spaces as well as its extremely observable means of voicing out hot topics as social and economic issues, among others. Its increasing fame indicates that social and cultural values are directly recognized.

In Jeddah, graffiti is written in two major languages: Arabic (first language) and English (second language). This includes graffiti written entirely in Arabic and in English, as well as pictorial graffiti as well as inscriptions involving code-switching between Arabic and English. The randomly selected samples, consist of graffiti, which are vandalism-free, legally allowed and contain no damaging nature, and are found in representative places such as University of Jeddah, King AbdulAziz University and in the north and the south of the city which generalize the entire province.

Many artists have emerged, among them is the young Saudi graphic designers "ḍ's family", who have created their own style to reserve the beauty of Arabic language by single out the most popular Arabic letter ض /ḍ/ (A1Mansouri, 2014). Sarah Mohanna Al Abdali is another popular artist in Jeddah who makes bold statements to question the social constraints in Saudi Arabia through spray painting walls in public places. (Davies, Maktabi \& Abdelhaq, 2012).

Figure (1) below, is a mural of a standard road sign to Mecca, the Saudi Arabian pilgrimage site for millions of Muslims every year. By zooming in, the portrait shows that the Ka'ba, the cube shaped building at the spiritual heart of Mecca, has been substituted by a combination of high buildings. This work was implemented by Sarah Mohanna Al Abdali, who sprayed it on walls around her home city of Jeddah as a comment on the rapid development in Mecca, the holiest Muslim city (Davies, Maktabi \& Abdelhaq, 2012). She once said that:

Saudi is going through a lot of change and street art is the perfect medium to experiment in. It's something very new here. I started with very random shapes but I wanted to develop more concepts that people could relate to. I like street art because it's there for people. You don't need to overdo your ideas. It's a simple way of expressing yourself. (Abdali, n.d. para.1)

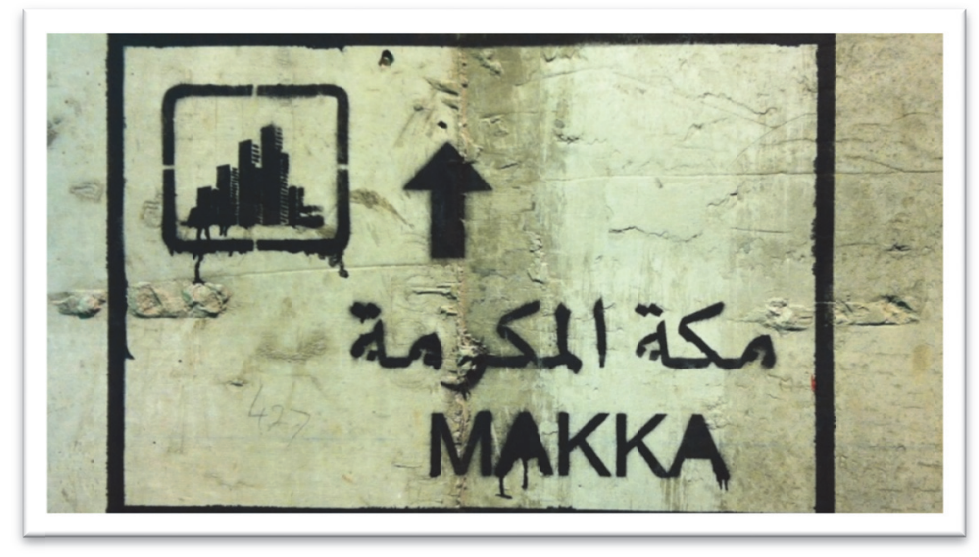

Figure 1: Makkah street Art (Al Abdali, n.d.) 
The rapidly developing art has evolved within the hip hop culture alongside other elements such as hip hop music, b-boying, and DJ-ing (Ross, 2016), (Baird \& Taylor, 2016) and (Crystal, 2001). Ferrell (1995) examines the various ways in which graffitists try to interpret their aspiration. Since graffiti writers remain anonymous, they can express their opinions freely, without the fear of criticism.

Unlike other official forms of the media (e.g. Twitter), graffiti are "one of the easiest and most efficient" means for people to voice taboo topics, religion, and sex because they provide a reachable communication medium with a good opportunity to avoid prosecution (Matthews et al., 2012: Mwangi et al., 2012). There is a whole language and complex hierarchy of graffiti out there that most people simply walk by every day without noticing. For this aspect, Hanauer (2004) viewed graffiti as a particular communicative act utilized by various subcultures to offer personal opinions in the public domain. Consequently,

"graffiti fulfills three functions of (a) allowing the entry within public discourse of messages regarded as marginal by other media; (b) providing the individual with the opportunity to express controversial contents publicly; and finally (c) it offers marginal groups the possibility of expressing themselves publicly" (p.29).

As was mentioned above, graffiti can represent people's voice in public places to depict their bother, prompt thoughts, feelings, or even their outcry (Farnia, 2014). In other words, they could be understood in terms of a second diary book (Raymonda, 2008) that reveals vital information to researchers interested in the investigation of the society's concerning issues.

Recently, graffiti started to be accepted as something with far more value due to the positive critical attention dedicated to works of such artists as Basquiat and Keith Haring in the 1980s, and the current works by Banksy,
Steve Powers, and the like (Ross, 2016). Since then, this subculture has flourished, and apparently connected to heritage through its popularity (Bates, 2014).

\subsection{Graffiti in the Arab world}

In many Middle Eastern countries, such as Lebanon, Tunisia, Egypt, Yemen, Libya and Syria, the word "graffiti" is linked to political activity. The graffiti movement in the Arab world arose to echo the experience in the region (Moukalled, 2013; Bar'el, 2017; Naeem, 2013). It was initiated with several scribbles and drawings by youths who "turned walls into newspapers" (Moukalled, 2013; Bar'el, 2017).

Graffiti in Syria contrasts with its counterparts in Lebanon and Egypt in terms of their nature as they are barren of high-level properties in visual image, and limited to short slogans, spontaneously created on the spot and written in a great rush (Naeem, 2013). Graffiti in the Arab World were limited to governments as the writings and paintings on Baghdad's walls were scribbled to glorify Saddam Hussein and his statements (Moukalled, 2013). A new wave of graffiti spread all over the Arab World beyond protest art as murals in Beirut and Djerba do not depict war, weapons or blood; they expel out the terror that splits Lebanese, familiarize them with international art and give them a sense of belonging (Bar'el, 2017).

\subsubsection{Graffiti in Saudi Arabia}

The quantity and the quality of the graffiti evident in Lebanon, especially in Beirut, and Egypt during the Egyptian revolution amazed and surprised people in Saudi Arabia, who were not really familiar with this kind of documenting the revolution events and conveying its message (Felemban, 2012). For most people in Saudi Arabia, the word graffiti is associated with the random statements all over the walls, such as " $\mathrm{A}+\mathrm{T}=<3$ " or "Abu Shanab" (Moustache Guy) or tags from different, mostly online, groups such as X5, 


\title{
Walls Have Ears: A critical Discourse Analysis OF Graffiti In Jeddah, Saudi Arabia
}

\author{
NUHA ALSHURAFA (Professor of linguistics at King Abdul-Aziz du.sa) \\ ALIA ALJOOFI (Teaching assistant, university of Jeddah, English language institute,
}

\begin{abstract}
Saudi graffiti in Jeddah with a special reference to communicative functions served by pictorial graffiti and their relation to the socio-cultural values of the society. It also investigates the distinctive lexical and syntactic features that characterize the language of graffitiwritings. The analysis of graffiti is based on Critical Discourse Analysis theory (CDA) as outlined by Van Dijk and Fairclough, extending the concept of discourse from the traditional and natural "language in use"' to a social one in practice. Through the analysis of 229 utterances and murals found in representative and legally allowed places in Jeddah including two universities: University of Jeddah, King Abdul- Aziz University and famous areas in the north and the south of the city, the results yield five categories that underline graffiti types in Jeddah. They are: Personal expressions, national expressions; social expressions; cultural (ideology) linguistic expressions; and finally Dysphemism (taboo) expressions within norms away from vandalism. The linguistic features of graffiti in Jeddah are found to have unique simplicity and creativity besides variation. It can be concluded that graffiti has idiosyncratic and prominent ways of vandalism-free and of no damaging nature of communication in the Saudi society. The study is believed to contribute in the field of discourse linguists, sociologists, psychologists, educators, administrators and parents. Since no prior study to this one has been conducted on Saudi graffiti, this project bridges the gap in the literature of linguistic studies of this area in the Middle East .

Keywords: Critical Discourse Analysis, Saudi graffiti in Jeddah, lexical and syntactic features, street art, socio-cultural values, sociolinguistics
\end{abstract}

\section{Introduction}

\subsection{Background of the study}

"Graffiti is not the lowest form of art. Despite having to creep about at night and lie to your mum, it's actually the most honest art form available." (Banksy, 2005, p.8)

Graffiti have been considered as a significant cultural and social phenomenon for a long time. They can be seen almost everywhere on the walls of public buildings, on the seats of public transportations, on the doors of washrooms at colleges, schools, institutes, etc. Faith, love, gender, family and other personal and social issues have always been the themes of graffiti, where their ways of depiction differ from place to place. Research has revealed that graffiti is as old as language itself. O'Doherty (2012) considers graffiti writing as the earliest form of human expression that preceded language in primitive times. This partly explains why societies are still involved in the practice of graffiti (Mangeya, 2014) 